\title{
EVALUASI KINERJA KEUANGAN PT PUPUK SRIWIJAYA DILIHAT DARI RASIO LIKUIDITAS
}

\section{JURNAL}

Diana Widhi Rachmawati

Dosen Prodi Akuntansi FKIP Universitas PGRI Palembang

Dianawidhi72@yahoo.com

MANAJEMEN

INDONESIA

Vol.17 No.3

Abstrak

Desember 2017

PT Pupuk Sriwijaya (PT Pusri), merupakan salah satu perusahaan besar sekaligus juga merupakan Badan Usaha Milik Negara (BUMN) yang memproduksi pupuk urea dan memasarkan ke segenap penjuru tanah air. Perusahaan ini merupakan salah satu perusahaan yang hingga kini dipandang cukup baik asset perusahaan yang dimilikinya, meliputi: empat pabrik yang dimiliki, kantor-kantor cabang yang berada hampir di seluruh ibu kota propinsi dan kantor pusatnya yang megah dan didirikan di Kotamadya Palembang, sehingga penulis melakukan penelitian dengan judul "Evaluasi Kinerja Keuangan PT Pupuk Sriwijaya dari sudut Likuiditas". Analisis Laporan Keuangan (Financial Statement Analysis) adalah aplikasi dari alat dan teknik analisis untuk laporan keuangan bertujuan umum dan data- data yang berkaitan untuk menghasilkan estimasi dan kesimpulan yang bermanfaat dalam analisis bisnis. Analisis Laporan Keuangan yang digunakan dalam penelitian ini menggunakan metode analisis ratio yaitu Ratio Likuiditas. Tujuan umumnya adalah untuk memberikan informasi perkembangan Kinerja Keuangan PT Pupuk Sriwijaya. Tujuan khusus sebagai evaluasi kinerja keuangan PT Pupuk Sriwijaya dari sudut likuiditas. Sampel dari penelitian ini adalah : PT Pupuk Sriwijaya. Hasil Akhir yang diperoleh dari penelitian ini adalah dapat dikatakan bahwa Evaluasi Kinerja Keuangan PT Pupuk Sriwijaya dari sudut Likuiditas cukup likuid, karena karena ketiga rasio yang terkandung didalamnya mengalami kenaikan. Harapannya bagi perkembangan PT Pupuk Sriwijaya, tetap konsisten dengan selalu berusaha melakukan semua terobosan demi tercapainya pencapaian tujuan perusahaan.

Kata Kunci : evaluasi kinerja keuangan

\begin{abstract}
PT Pupuk Sriwijaya is one of the big company State-owned enterprises which producing urea fertilizer and marketing to all over iIndonesia. The asset of this company include : four factory, the branch office almost in all capital province, and a big office in the capital city, so that the author make a research about evaluation of finance performance PT Pupuk Sriwijaya from Liquidity side. The financial statement analysis is the application from the tools and analysis teqniques for financial report for a general purposes and related data to generates the estimation and conclution that very useful in business analysis. The general purposes is to give an information about performance improvment financial of PT Pupuk Sriwijaya. The special purposes is to evaluating the financial performance PT Pupuk Sriwijaya from liquidiy side. The sample of this research is PT. Pupuk Sriwijaya. The final result obtained that we can say the financial statement analysis PT Pupuk Sriwijaya from liquidiy side is quite liquid, because three of the ratio which contain on it is increasing. It's expected that PT Pupuk Sriwijaya to keep consistant and always try to make a new inovation to achive the company aim.
\end{abstract}

Keyword : Finance performance evaluated

EVALUASI KINERJA KEUANGAN... 


\section{Pendahuluan}

Pasar bebas adalah suatu perdagangan dunia yang bersifat "open trade" atau perdagangan terbuka, maksudnya hampir seluruh dunia diberlakukan suatu dalam jumlah yang cukup besar dan beragam dengan mudahnya karena bea atas impor barang yang biasanya dikenakan atas barang yang masuk ke dalam suatu negara mulai dikurangi bahkan kemungkinan besar dihapuskan. Diharapkan persaingan yang ditimbulkan oleh barang yang masuk termasuk dengan barang produksi yang sama jenisnya dan dihasilkan oleh produk dalam negeri di "pasaran" dapat bersaing dengan ketat dan sehat; itu diperlukan kemampuan dari barang produksi dalam negeri mengimbangi produk yang dihasilkan dari negara luar.

Namun untuk dapat mengimbangi hasil produk luar negeri tidaklah mudah karena bukan saja dibutuhkan modal yang cukup besar untuk memperbaiki kualitas dan kuantitas produk tetapi juga dibutuhkan kejelian pengamatan yang dilakukan oleh bidang pemasaran untuk mengemas produk sebaik mungkin sekaligus memberikan nilai tambah pada produk tersebut dan mendistribusikannya. Tidak hanya itu diberlakukan juga bantuan dari bidang produksi untuk menghasilkan produk yang bermutu baik dan juga bidang sumber daya manusia untuk memberikan pengarahan dan pengaturan akan pembagian kerja yang baik sehingga semua bidang dapat melakukan pekerjaan sesuai dengan bidangnya masing-masing.

Keselarasan kerja tersebut dapat terwujud dengan kehadiran bidang keuangan. Sebagaimana kita ketahui bidang keuangan berhubungan dengan pemberian gaji ataupun bonus kepada karyawan suatu perusahaan. Tetapi sebenarnya tidak hanya itu saja tugas bidang keuangan yang utama adalah mengelola harta perusahaan dan mendistribusikannya kepada seluruh bidang agar seluruh bidang dapat melakukan aktivitas dengan baik.

Dengan mengelola harta perusahaan tidak dipungkiri lagi bahwa itu berhubungan pula dengan cara pengelolaan sumber-sumber daya yang dibutuhkan oleh perusahaan, dan sumbersumber daya tersebut meliputi modal, alam, keahlian dan manusia. Perusahaan dala hal ini bidang keuangan harus mampu menyelaraskan sumber-sumber daya tersebut untuk dapat bekerja dan saling mendukung sama lain. Sehubungan dengan keselarasan kerja perusahaan dengan lokasi penelitian pada kantor pusat PT PUPUK SRIWIJAYA di Palembang maka permasalahan yang diambil adalah bagaimana evaluasi kinerja keuangan perusahaan tahun 1996 -1999 dilihat dari rasio likuiditasnya?

Mengevaluasi sekaligus menganalisa keuangan tahun 1996 - 1999 dari sudut rasio likuiditas

1. Internal Dapat dipergunakan perusahaan sebagai bahan pertimbangan untuk memperbaiki kekurangan dan mempertahankan kualitas kinerja yang telah dianggap baik

2. Eksternal Dapat dipergunakan oleh para pemegang saham atau investor dan masyarakat luas untuk mengetahui dan menambah informasi secara lebih mendalam tentang keadaan kinerja PT Pupuk Sriwidjaya ( PT PUSRI ) Palembang

\section{Landasan Teori}

\subsection{Manajemen Keuangan}

Menurut Rue dan Buyers (2000), manajemen adalah proses pemberian panduan ataupun petunjuk pelaksanaan terhadap beberapa orang untuk mencapai sasaran dan tujuan secara orgasisional. Menurut Keown dkk (1999), keuangan berkepentingan dengan bagaimana cara menciptakan dan menjaga nilai ekonomis atau kesejahteraan yang mempunyai konsekuensi dalam pengambilan keputusan dengan fokus pada penciptaan kesejahteraan.

Jadi manajemen keuangan dapat didefinisikan sebagai suatu proses pemberian panduan atau petunjuk pelaksanaan yang berpengaruh dalam pengambilan keputusan di bidang keuangan pada suatu aktivitas keuangan. Manajer merupakan pelaksana dari kegiatan manajemen karena ruang lingkup pembahasan hanya berfokus kepada manajemen keuangan. Jadi sebagai 
pelaksana dibidang keuangan adalah manajer keuangan. Brigham dan Houston (2001) mendefinisikan manajemen keuangan sebagai tugas pokok dari manajer keuangan.

\subsection{Laporan Keuangan}

Tugas seorang manajer keuangan cukup banyak dimana seorang manajer tidak hanya ditunjuk untuk menunjuk dedikasi yang tinggi dan loyal kepada perusahaan tetapi juga kemampuan dan kemauan yang keras juga memiliki wawasan yang luas dan mempunyai data yang terlebih dahulu telah diterima dari bidang-bidang lain serta melakukan pencatatan kembali setelah terlebih dahulu melakukan pengelompokan data berdasarkan pos-pos yang telah ditentukan sebelumnya. Kemudian disusun dan dilakukan penghitungan dengan cermat sebelum melakukan tahap akhir

Laporan keuangan dibuat dengan maksud memberikan gambaran atas laporan keuangan secara periodik yang dilakukan manajemen perusahaan, diamana laporan keuangan itu bersifat historis dan menyeluruh. Dengan mengadakan analisa terhadap pos-pos neraca akan dapat diketahui gambaran tentang posisi keuangan, sedangkan analisa terhadap laporan laba ruginya akan dapat melihat perkembangan kinerja perusahaan serta hasil-hasil yang telah dicapai oleh perusahaan tersebut perlu adanya laporan keuangan dari perusahaan yang bersangkutan, dimana hasil dari analisa laporan keuangan tersebut merupakan dasar bagi pihak-pihak yang berkepentingan untuk mengambil keputusan.

Menurut Syamsuddin (1992), ada tiga kelompok yang paling berkepentingan dengan rasio-rasio keuangan, yaitu para pemegang saham dan calon pemegang saham, kreditur dan calon kreditur serta manajemen perusahaan. Para pemegang saham dan calon pemegang saham menaruh perhatian utama pada tingkat keuangan, baik yang sekarang maupun kemungkinan tingkat keuntungan pada masa yang akan datang. Hal ini sangat penting bagi para pemegang dan calon pemegang saham karena tingkat keuntungan akan mempengaruhi harga saham-saham yang mereka miliki.

Para Kreditur pada umumnya merasa kepentingan terhadap kemampuan perusahaan dalam membayar kewajiban-kewajiban finansial baik jangka pendek maupun jangka panjang. Kreditur yang pada saat ini sudah memberikan pinjaman kepada perusahaan ingin mendapatkan suatu jaminan bahwa perusahaan tempat mereka menanamkan modalnya akan mampu membayar bunga dan pinjaman pokok tepat pada waktunya. Sedangkan calon kreditur lebih menekankan pada struktur finansial dan struktur modal perusahaan.

Kelompok ketiga yang juga berkepentingan dengan rasio finansial ini adalah manajemen perusahaan sendiri. Manajemen perusahaan menyadari hal-hal tersebutlah yang akan dinilai oleh pemilik perusahaan atau para kreditur. Jadi sudah tentu dalam hal ini manajemen perusahaan akan selalu berusaha akan mempertahankan rasio-rasio yang dianggap baik oleh kedua kelompok di atas.

Dalam laporan keuangan disajikan dengan meliputi tiga hal utama, yaitu :

a. Laporan rugi laba ( Income Statement)

Laporan rugi/laba merupakan upaya untuk mengukur hasil bersih yang dihasilkan selama waktu tertentu, bisa selama satu bulan, enam bulan atau setahun. Laporan rugi/laba tidak bersifat tunai atau seketika (cash basis) melainkan bersifat akumulatif (acrual).

b. Neraca (Balance Sheet)

Neraca merupakan sebuah laporan mengenai posisi keuangan perusahaan pada saat itu atau periode tertentu meliputi kepemilikan aktiva (asset), hutang (Long Term \& Short Term) dan modal pemilik (Equity). Aktiva adalah semua harta/kekayaan yang dimiliki perusahaan sedangkan hutang modal sumber-sumber pembiayaan atau pengadaan aktiva terdebut.

c. Laporan Arus Kas

Laporan arus kas merupakan pencatatan kas masuk dan kas keluar dari suatu perusahaan yang menggunakan keterangan-keterangan yang diperoleh dari neraca dan laporan rugi/laba. 


\subsection{Analisa Laporan Keuangan}

Tujuan utama analisa adalah untuk memperoleh pandangan dan gambaran yang lebih baik tentang masalah operasional dan keuangan yang dihadapi perusahaan. Syamsuddin (2007) berpendapat bahwa analisa laporan keuangan perusahaan pada dasrnya merupakan perhitungan rasio-rasio untuk menilai keadaan keuangan perusahaan di masa lalu, saat ini dan kemungkinan di masa depan. Kemudian Riyanto dan Perusahaan (1998) dalam bukunya Dasar-Dasar Pembelanjaan menyatakan untuk memperoleh gambaran tentang perkembangan finansial suatu perusahaan perlulah kita mengadakan interpretasi analisa terhadap data finansial dari perusahaan yang bersangkutan, dimana laporan keuangan tersebut memberikan ikhtisar mengenai keadaan finansiil suatu perusahaan dimana neraca (balance sheet) mencerminkan nilai aktiva, hutang dan modal sendiri pada suatu saat tertentu dan lapaoran laba/rugi (Income Statement) mencerminkan hasil-hasil yang dicapai dalam suatu periode tertentu biasanya meliputi periode satu tahun.

Mengadakan intrerpretasi analisa terhadap laporan keuangan dari suatu perusahaan akan sangat bermanfaat bagi penganalisa untuk dapat mengetahui keadaan dan perkembangan (kinerja) keuangan perusahaan yang bersangkutan. Pimpinan perusahaan atau manajer sangat berkepentingan laporan keuangan dari perusahaan yang dipimpinnya.

Adapun menurut Brigham dkk (1998) mengenai analisa laporan keuangan menjelaskan bahwa analisis laporan keuangan pada umunya berasal dari asset atas rasio-rasio keuangan yang diciptakan untuk mengetahui kekuatan-kekuatan dan kelemahan-kelemahan yang sifatnya relatif pada suatu perusahaan sebagai pembanding terhadap perusahan lain sejenis dan untuk menunjukkan apakah posisi perusahaan telah mengalami perbaikan atau penurunan selama tahun-tahun yang telah berjalan.

Dengan mengadakan analisa laporan keuangan, manajer perusahaan akan dapat mengetahui keadaan dan perkembangan keadaan keuangan perusahaannya dapat diketahui hasil-hasil keuangan yang telah dicapai pada masa lalu, sekarang dan masa depan; juga dapat mengetahui kelemahan-kelemahan ataupun kekuatan perusahaan sehingga bisa memperbaiki kelemahan yang timbul dan mempertahankan kekuatan.

\subsection{Metode dan Teknik Analisa Laporan Keuangan}

Sebelum mengadakan perhitungan, analisa dan interpretasi, terlebih dahulu harus mempelajari atau mereview secara menyeluruh dan jika dianggap perlu diadakan rekonstruksi dari data sesuai dengan prinsip-prinsip yang berlaku dan tujuan analisa. Maksudnya adalah untuk meyakinkan bahwa laporan tersebut sudah cukup jelas menggambarkan semua data yang relevan dan telah diterapkannya prosedur akuntansi maupun metode penilaian yang tepat, sehingga betul-betul mendapatkan laporan keuangan yang dapat diperbandingkan (comparable). Analisa - analisa laporan keuangan terdiri dari penelaahan atau mempelajari dari hubungan-hubungan dan tendensi atau kecenderungan (trend) untuk menentukan posisi keuangan dan hasil operasi serta perkembangan perusahaan yang bersangkutan. Metode dan teknik dan analisa digunakan untuk memenuhi dan mengukur hubungan antara pos-pos yang dalam laporan, sehingga dapat diketahui perubahan-perubahan masing-masing pos tersebut bila dibandingkan dengan laporan dari beberapa periode untuk perusahaan tersebut, atau diperbandingkan dengan alat-alat pembanding lainnya, misalnya dibandingkan dengan laporan keuangan yang dibudget atau dengan laporan keuangan perusahaan lainnya.

Tujuan dari setiap model atau teknik analisa adalah untuk menyederhanakan data sehingga dapat lebih dimengerti. Pertama-tama data yang diperlukan dikumpulkan, diukur dan kemudian dianalisa dan diinterpretasikan sehingga data ini menjadi lebih berarti. Ada dua metode analisa yang digunakan oleh setiap penganalisa laporan keuangan, yaitu analisa horizontal dan analisa vertikal. 
Analisa Horizontal adalah analisa dengan mengadakan perbandingan laporan keuangan untuk beberapa periode atau beberapa saat, sehingga akan diketahui perkembangannya. Metode horizontal ini disebut pula sebagai metode analisa dinamis.

Analisa vertikal yaitu apabila laporan keuangan yang dianalisanya hanya meliputi satu periode atau satu saat aja, yaitu dengan membandingkan antara pos yang satu dengan pos yang lain dalam laporan keuangan tersebut, sehingga akan diketahui keadaan keuangan atau hasil operasi pada saat itu saja. Analisa vertikal ini disebut juga sebagai metode analisa yang statis, karena kesimpulan yang dapat diperoleh hanya untuk periode itu saja tanpa mengetahui perkembangannya.

Munawir (1981), dalam bukunya analisa laporan keuangan menyebutkan teknik analisa yang biasa digunakan dalam analisa laporan keuangan adalah sebagai berikut :

1) Analisa Perbandingan Laporan Keuangan

2) Trend dalam Presentase

3) Laporan dengan Persentase Perkomponen

4) Analisa Sumber dan Penggunaan Sumber Kerja

5) Analisa Rasio

6) Analisa Perubahan Laba Kotor

7) Analisa Break Even

Metode dan teknik analisa manapun yang digunakan, kesemuanya itu adalah permulaan dari proses analisa yang diperlukan untuk menganalisa laporan keuangan, dan setiap metode analisa memiliki tujuan yang sama, yaitu agar data dapat lebih dimengerti sehingga dapat digunakan sebagai dasar pengambilan keputusan bagi pihak-pihak yang membutuhkan.

\subsection{Analisa Rasio Keuangan}

Dalam mengadakan interpretasi dan analisa kinerja laporan keuangan suatu perusahaan, seorang analisis memerlukan adanya aturan tertentu. Ukuran yang sering digunakan dalam analisa finansiil salah satunya adalah analisa rasio. Riyanto dan Perusahaan (1998), penganalisa dalam menganalisa rasio finansiil pada dasarnya dapat dilakukan dengan dua macam perbandingan, yaitu :

a. Membandingkan rasio sekarang (present ratio) dengan rasio dari waktu-waktu yang lalu (historical ratio) atau dengan ratio-ratio yang diperkirakan untuk waktu-waktu yang akan dari perusahaan yang sama. Misalnya current ratio tahun 1996 dibandingkan current ratio dari tahun-tahun sebelumnya.

b. Membandingkan rasio-rasio dari suatu pemisahan dengan rasio-rasio semacam dari perusahaan lain sejenis atau rasio industri (ratio standard) untuk waktu yang sama.

Analisa Laporan Keuangan, khususnya mencurahkan perhatian kepada perhitungan rasio agar dapat mengevaluasi keadaan finansiil pada masa yang lalu, sekarang dan memproyeksikan pada masa yang akan datang. Alwi (2001), Analisa Rasio merupakan bentuk atau cara yang umum digunakan dalam analisa laporan keuangan, kata lain di antara alat-alat analisa yang selalu digunakan untuk mengukur kekuatan atau kelemahan yang dihadapi perusahaan dibidang keuangan.

Untuk keperluan analisa rasio-rasio finansial Brigham dan Houston (2001), menggolongkan rasio-rasio keuangan, yaitu :

a. Rasio Likuiditas mengukur kemampuan perusahaan untuk memenuhi kewajiban jangka pendeknya atau kemampuan perusahaan untuk memenuhi kewajiban keuangan pada saat ditagih.

b. Rasio Aktivitas mengukur sejauh mana efektivitas penggunaan aset dengan melihat tingkat aktivitas aset 


\section{JURNAL}

MANAJEMEN

INDONESIA

\section{Vol.17 No.3}

Desember 2017 c. Rasio Solvabilitas mengukur sejauh mana kemampuan perusahaan memenuhi kewajiban-kewajiban jangka panjangnya

d. Rasio Profitabilitas mengukur seberapa kemampuan perusahaan menghasilkan laba (profitabilitas)

e. Rasio Pertumbuhan (growth ratio) yang mengukur kemampuan mempertahankan posisi ekonomi dan industri.

f. Rasio Penilaian (valuation ratio) yang mengukur kemampuan manajemen dalam menciptakan nilai pasar yang melampaui pengeluaran biaya investasi.

Sedangkan Riyanto dan Perusahaan (1998) mengklasifikasikan rasio-rasio finansiil ke dalam empat golongan, yaitu :

a. Rasio likuiditas

b. Rasio leverage

c. Rasio aktivitas

d. Rasio profitabilitas

Dalam hal ini pembahasan hanya dibatasi dalam ruang lingkup Rasio Likuiditas, dimana, rasio ini dimaksudkan untuk mengukur kemampuan perusahaan membayar kewajiban perusahaan membayar kewajiban jangka pendeknya dengan tepat waktu. Rasio-rasio yang termasuk rasio likuditas, antara lain:

1. Current Ratio (Rasio Lancar), yaitu kemampuan untuk membayar kewajiban lancarnya dengan aktiva lancar yang tersedia. Ukuran tingkat current ratio yang baik untuk masing-masing perusahaan berbeda satu sama lain. Ada kebiasaan yang menentukan tingkat current ratio yang baik adalah 200\%. Tetapi hal ini tidaklah mutlak, sebab modal kerja bersih (net working capital) adalah current asset dikurangi current liabilities, denga perbandingan 2:1, maka modal kerja adalah 1. Namun baik buruknya current ratio tergantung pada komposisi current asset terhadap liabilities. Tingkat current ratio yang terlalu tinggi menunjukkan bahwa aktiva lancar kurang produktif, karena banyaknya uang kas yang menganggur atau persediaan yang melebihi kebutuhan dapat mengakibatkan inefisiensi. Sebaliknya current ratio yang terlalu rendah mengakibatkan perusahaan mengalami kualitas dalam memenuhi kewajiban jangka pendeknya.

2. Cash Ratio adalah kemampuan untuk membayar kewaiban yang harus segera dipenuhi dengan kas yang tersedia dalam perusahaaan, bank dan efek yang dapat segera diuangkan. Cash ratio yang terlalu rendah menunjukkan perusahaan mengalami kesulitan untuk memenuhi kewajiban yang segera harus dipenuhi dengan kas dan efek yang dimiliki. Sedangkan cash ratio yang terlalu tinggi menunjukkan dana yang tertanam dalam kas dan efek tidak produktif.

3. Quick Ratio adalah kemampuan untuk membayar kewajiban yang harus segera dipenuhi dengan aktiva lancar yang lebih likuid. Karena rasio ini tidak memasukkan komponen persediaan dalam perhitungan, maka perlu diingat bahwa bagi perusahaan jasa atau perusahaan yang tidak mempunyai persediaan, rasio ini perlu dihitung. Adapun ukuran umum Quick Ratio adalah $100 \%$.

Menurut Syamsuddin (2007) ada dua cara yang dapat dilakukan dalam membandingkan rasio finansial, yaitu cross sectional approach dan time series analysis. Yang dimaksud dengan cross sectional approach adalah suatu cara mengevaluasi dengan cara membandingkan rasiorasio antara perusahaan yang satu dengan perusahaan lainnya yang sejenis pada saat yang bersamaan. Pembanding dengan cara ini juga dapat dilakukan dengan jalan membandingkan rasio finansial perusahaan dengan rasio rata-rata industri. Sedangkan untuk time series analysis dilakukan dengan jalan membanding rasio-rasio finansial perusahaan dari satu periode ke periode lainnya. Pembanding antara rasio yang dicapai saat ini dengan rasio-rasio yang masa lalu akan memperlihatkan apakah perusahaan mengalami kemajuan atau kemunduran.

Tanpa adanya dasar pembandingan (standard of comparison), maka rasio-rasio sebagai indikator tidaklah mempunyai kegunaan sama sekali. Selain ini disebutkan di atas, yang dapat dijadikan standard of comparison menurut Reksoprayitno (2000) adalah: 
Rasio keuangan yang sama dari perusahaan yang sama dari tahun-tahun sebelumnya (rasio historis)

$>$ Rasio-rasio keuangan yang sama dari perusahaan yang sama telah ditetapkan sebagai rasio yang ideal.

$>$ Rasio-rasio keuangan dari perusahaan yang sama untuk periode pembukuan yang sama atau yang bersangkutan, yang ada hubungannya dengan rasio keuangan yang ingin kita temukan tafsiran atau maknanya yang tepat.

$>$ Rasio yang sama dari perusahaan-perusahaan yang sejenis untuk periode yang sama.

$>$ Rasio rata-rata dari perusahaan sejenis (rasio industri) untuk periode yang sama, angka pembanding ini biasa disebut standard financial ratio atau rasio keungan standar.

$>$ Pendapat pribadi dari penganalisa sendiri

JURNAL

MANAJEMEN

INDONESIA

Vol.17 No.3

Desember 2017

Untuk Indonesia jika perusahaan-perusahaan mengadakan analisa kinerja laporan keuangan dengan analisa, pada saat ini hanya dapat mengadakan analisa rasio sendiri

\section{Metodologi Peneitian}

\subsection{Kerangka Pemikiran}

Penelitian ini mengambil pokok permasalahan tentang evaluasi kinerja keuangan pada tahun 1996-1999 berdasarkan rasio Likuiditas. Untuk menjawab pokok permasalahan tersebut, digunakan analisa rasio keuangan yang berpatokan pada Laporan Tahunan Perusahaan dalam hal ini PT Pupuk Sriwijaya yang meliputi neraca laporan laba/rugi dengan menggunakan rasio likuiditas sebagai landasan kerjanya.

Perhitungan kinerja atas PT Pupuk Sriwijaya diperlakukan sama dengan perhitungan kinerja perusahaan swasta lainnya tidak dilihat dari perhitungan yang sudah ditetapkan oleh pemerintah atas perusahaan BUMN (Badan Usaha Milik Negara) yang biasanya lebih ringan karena PT Pupuk Sriwijaya merupakan salah satu BUMN yang mendapat subsidi dari pemerintah.

\section{a. Metode Pengumpulan Data}

Data dan informasi yang akan digunakan diperoleh dari sumber primer dan sumber sekunder, yaitu:

1. Penelitian Kepustakaan

Penelitian yang digunakan untuk mendapatkan landasan teori yang akan dipakai dalam pembahasan dan mencari alternatif-alternatif pemecahan masalah melaui buku-buku dan artikel-artikel yang berkaitan.

2. Penelitian Lapangan

Pengumpulan data yang diperlukan dengan cara mendatangi perusahaan yang menjadi objek penelitian, selanjutnya melakukan wawancara langsung terhadap beberapa orang tertentu pada perusahaan tersebut untuk melengkapi data yang diperoleh.

\section{b. Metode Analisis Data}

Penulis mencoba mendekati permasalahan dengan melakukan analisis data dengan cara mengetahui kualitas kinerja keuangan PT Pusri, melalui alat-alat analisis manajemen keuangan, seperti

- Laporan laba rugi

- Neraca

- Analisis rasio

Setelah data diperlukan diperoleh, selanjutnya dilakukan analisis terhadap kinerja keuangan perusahaan. Analisis ini dilakukan dengan mendasarkan pada teori-teori yang telah diperoleh dari studi kepustakaan. 
Sebagaimana telah dipaparkan sebelumnya bahwa dalam melakukan analisis ini, digunakan analisa rasio antara komponen-komponen Neraca dan Laporan laba rugi selama penelitian, dimana kali ini pembahasan hanya dibatasi pada Rasio Likuiditasnya, dan Rasio Likuiditas itu sendiri terbagi atas :

* Current ratio, rumusnya :

MANAJEMEN

INDONESIA

\section{Vol.17 No.3}

Desember 2017
Tabel 1 PT PUPUK

\section{SEIWIJAYA}

Neraca per 31

Desmber 1996

1999

Sumber : Data

Olahan dari

Laporan Keuangan

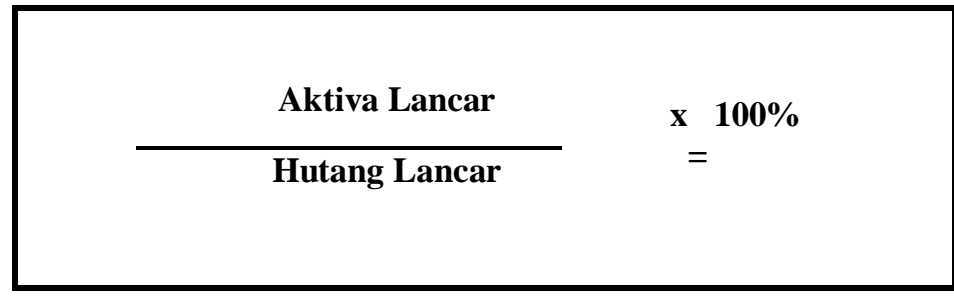

* Cash ratio, rumusnya :
Kas + Efek

Hutang Lancar
X $100 \%$

$=$
Kas + Efek +

Piutang

Hutang Lancar x $100 \%$

$=$
4. Hasil Penelitian dan Pembahasan

\subsection{Hasil Penelitian}

\begin{tabular}{|c|c|c|c|c|}
\hline \multirow{2}{*}{ KETERANGAN } & \multicolumn{4}{|c|}{ TAHUN } \\
\hline & 1996 & 1997 & 1998 & 1999 \\
\hline \multicolumn{5}{|l|}{$\begin{array}{l}\text { AKTIVA } \\
\quad \text { Aktiva Lancar }\end{array}$} \\
\hline Kas dan setara kas & 339.995 .300 & 458.180 .219 & 1.104 .042 .789 & 703.240 .413 \\
\hline Total piutang & 287.317 .853 & 401.920 .569 & 534.624 .317 & 497.775.209 \\
\hline Uang muka & 3.603 .050 & 3.048 .636 & 61.152 .462 & 116.460 .318 \\
\hline Total persediaan & 369.095 .631 & 505.563 .067 & 371.371 .417 & 423.544 .380 \\
\hline $\begin{array}{l}\text { Pajak yang dibayar } \\
\text { di muka }\end{array}$ & 6.083 .953 & 9.319 .565 & 10.473 .025 & 60.908 .758 \\
\hline $\begin{array}{l}\text { Biaya yang dibayar } \\
\text { di muka }\end{array}$ & 6.657 .125 & 9.177 .872 & 76.782 .487 & 9.372 .775 \\
\hline Jumlah aktiva lancar & 1.012 .752 .912 & 1.387.209.928 & 2.158 .446 .497 & 1.811 .301 .853 \\
\hline
\end{tabular}

Jurnal Manajemen Indonesia 


\begin{tabular}{|c|c|c|c|c|}
\hline \multirow{2}{*}{ KETERANGAN } & \multicolumn{4}{|c|}{ TAHUN } \\
\hline & 1996 & 1997 & 1998 & 1999 \\
\hline Jumlah investasi & 85.668 .716 & 2.390 .926 .113 & 3.513 .287 .453 & 3.998 .153 .834 \\
\hline Jumlah aktiva tetap & 703.195.179 & 626.696 .922 & 551.337 .641 & 531.515 .361 \\
\hline Jumlah aktiva lain-lain & 118.799 .119 & 138.615.673 & 122.150 .074 & 156.087 .380 \\
\hline JUMLAH AKTIVA & 1.920 .415 .926 & 4.543.448.636 & 6.345 .221 .665 & 6.497.058.428 \\
\hline $\begin{array}{l}\text { KEWAJIBAN DAN } \\
\text { MODAL } \\
\text { Jumlah kewajiban jk } \\
\text { pendek }\end{array}$ & 532.212 .965 & 736.085 .562 & 996.352 .580 & 632.503 .176 \\
\hline $\begin{array}{l}\text { Jumlah kewajiban jk } \\
\text { panjang }\end{array}$ & 278.788.706 & 228.961 .918 & 145.970 .130 & 93.544 .592 \\
\hline Kewajiban lain-lain & 235.812 & 1.188 .688 & 4.769 .388 & 10.792 .183 \\
\hline JUMLAH KEWAJIBAN & 811.237 .483 & 966.236 .168 & 1.147.092.098 & 736.839 .951 \\
\hline $\begin{array}{l}\text { Tambahan Modal } \\
\text { Pemerintah }\end{array}$ & 50.742 .620 & & & \\
\hline Jumlah modal saham & 500.000 .000 & 2.900 .000 .000 & 2.900 .000 .000 & 2.900 .000 .000 \\
\hline $\begin{array}{l}\text { Jumlah laba yang } \\
\text { ditahan }\end{array}$ & 558.435 .823 & 677.212 .468 & 2.298 .129 .567 & 2.860 .218 .477 \\
\hline Jumlah modal & 1.109.178.443 & 3.577 .212 .468 & 5.198 .129 .567 & 5.760 .218 .477 \\
\hline $\begin{array}{l}\text { JUML KEWAJIBAN DAN } \\
\text { MODAL }\end{array}$ & 1.920 .415 .926 & 4.543.448.636 & 6.345 .221 .665 & 6.497.058.428 \\
\hline
\end{tabular}

JURNAL

MANAJEMEN

INDONESIA

Vol.17 No.3

Desember 2017

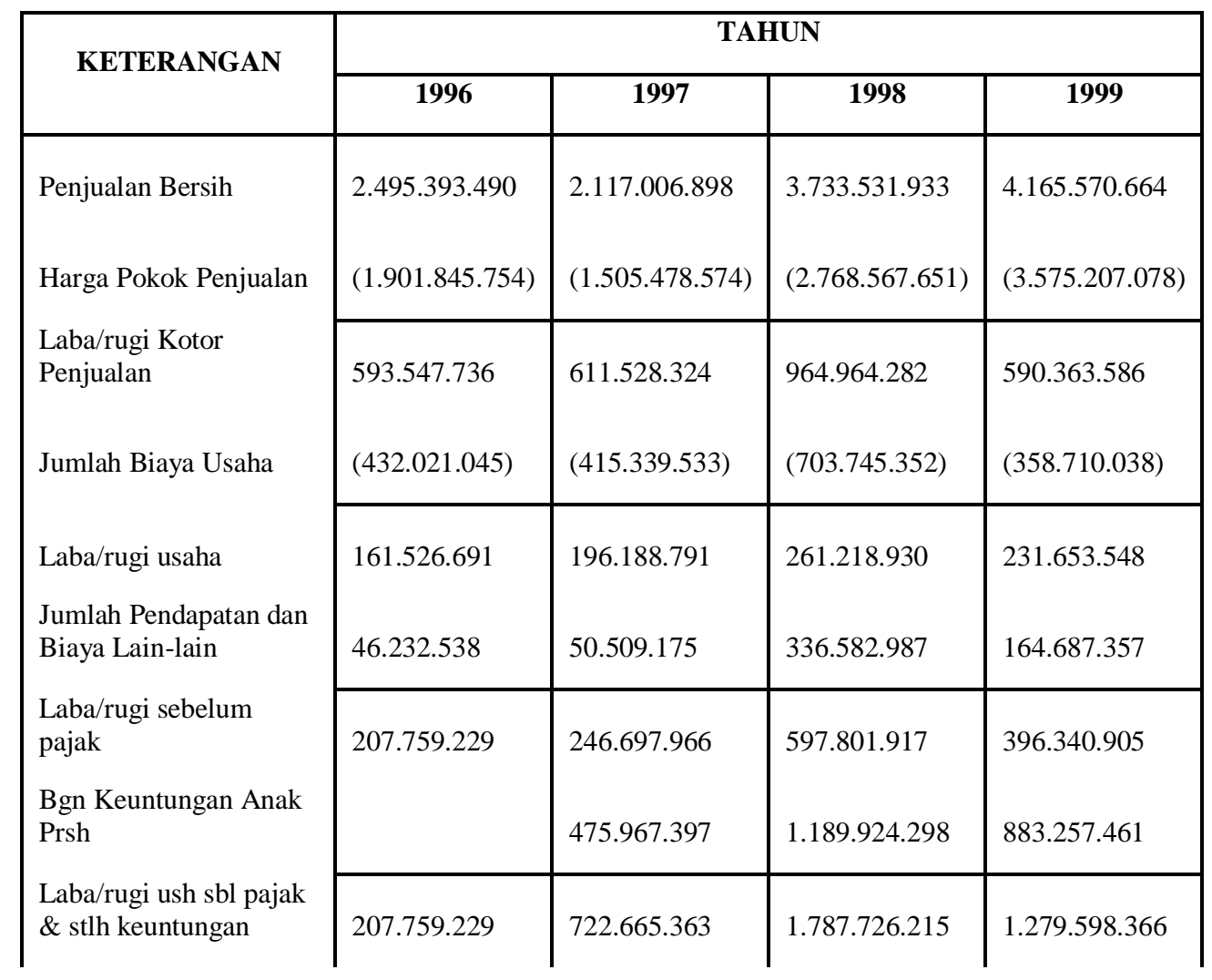

Tabel 2 PT PUPUK

SRIWIJAYA

Laporan Laba Rugi

Per 31 Desember

$1996-1999$

Sumber : Data

Olahan dari Laporan

Tahunan

EVALUASI KINERJA KEUANGAN... 


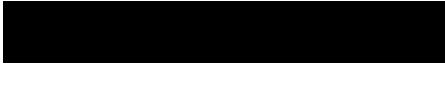

\section{JURNAL}

MANAJEMEN

INDONESIA

\section{Vol.17 No.3}

Desember 2017

Tabel 3 PT

PUPUK

SRIWIJAYA

Rasio Keuangan

Likuiditas

Tahun 1996 -

1999

Sumber : Hasil

Analisis

Tabel 4

Kelebihan

Aktiva Lancar

Atas Hutang

Lancar

Sumber : Hasil

Analisis

\begin{tabular}{|c|c|c|c|c|}
\hline \multirow{2}{*}{ KETERANGAN } & \multicolumn{4}{|c|}{ TAHUN } \\
\hline & 1996 & 1997 & 1998 & 1999 \\
\hline \multirow{2}{*}{$\begin{array}{l}\text { Pajak } \\
\text { Laba/rugi usaha stlh } \\
\text { pajak }\end{array}$} & 48.420 .095 & 60.235 .909 & 84.813 .473 & 90.590 .150 \\
\hline & 159.339 .134 & 662.429 .454 & 1.702 .912 .742 & 1.189 .008 .216 \\
\hline
\end{tabular}

Berdasarkan hasil perhitungan berdasrkan rumus yang ada diperoleh hasil seperti yang ditunjukkan dalam tabel berikut ini :

\begin{tabular}{|c|c|c|c|c|c|}
\hline \multirow{2}{*}{ No } & \multirow{2}{*}{ Rasio - rasio } & \multicolumn{4}{|c|}{ Tahun } \\
\cline { 3 - 6 } & & $\mathbf{1 9 9 6}$ & $\mathbf{1 9 9 7}$ & $\mathbf{1 9 9 8}$ & $\mathbf{1 9 9 9}$ \\
\hline 1 & Current Ratio & $190,30 \%$ & $188,40 \%$ & $216,60 \%$ & $286,40 \%$ \\
\hline 2 & Cash Ratio & $63,90 \%$ & $62,20 \%$ & $110,80 \%$ & $111,20 \%$ \\
\hline 3 & Quick Ratio & $117,90 \%$ & $116,80 \%$ & $163,40 \%$ & $189,90 \%$ \\
\hline
\end{tabular}

\subsection{Pembahasan}

PT Pupuk Sriwijaya termasuk perusahaan yang "likuid" ini terlihat dari rasio, baik current ratio, cash ratio dan quick ratio, angka-angkanya mendekati $100 \%$ bahkan ada yang mencapai $200 \%$ lebih. Pada tahun 1996, current ratio menunjukkan angka 190,3\% hal ini berarti bahwa untuk setiap Rp. 1,00 hutang lancar dijamin oleh aktiva lancar sebesar 1,90 sehingga masih terdapat kelebihan aktiva lancar sebesar 0,90 atau terdapat $90 \%$ kelebihan aktiva lancar daripada hutang lancar dan ini menguntungkan sekali untuk dapat membantu pelaksanaan perusahan. Lalu bagaimana keadaannya dengan tiga tahun berikutnya, yang dapat kita lihat dengan jelas melalui tabel berikut :

\begin{tabular}{|c|c|c|c|}
\hline Tahun & Current Ratio & $\begin{array}{c}\text { Penjaminan } \\
\text { Hidup Aktiva } \\
\text { Lancar }\end{array}$ & $\begin{array}{c}\text { Kelebihan Aktiva } \\
\text { Lancar daripada } \\
\text { Hutang Lancar }\end{array}$ \\
\hline 1997 & $188,40 \%$ & 1,88 & $88 \%$ \\
\hline 1998 & $216,60 \%$ & 2,17 & $117 \%$ \\
\hline 1999 & $286,40 \%$ & 2,86 & $186 \%$ \\
\hline
\end{tabular}

Dari tabel 4 tersebut terlihat jelas dari tahun 1996 -1999, Current Ratio terus beranjak baik, hal ini berarti semakin likuidnya, perusahaan untuk dapat mengembalikan semua hutang lancar yang mereka pinjam selama ini dengan pinjaman sesuai dengan aktiva lancarnya. Bagaimana halnya dengan neraca per 31 Desember dari tahun 1996 - 1999, penekanan utama masih tetap pada posisi aktiva lancar atau posisi hutang lancar pada perbandingan prosentase pertambahan maupun penurunan yang terjadi pada keduanya yang dapat kita lihat dengan jelas melalui tabel berikut :

Jurnal Manajemen Indonesia 


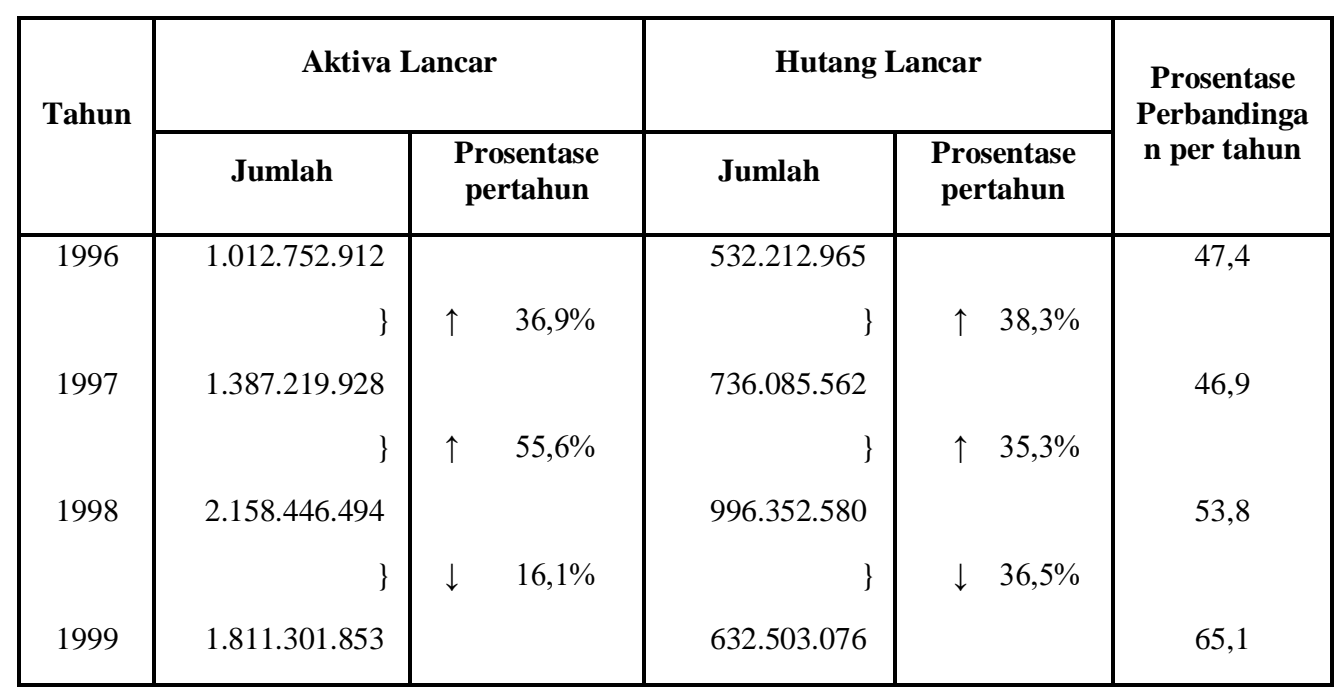

Berdasarkan tabel 5 terlihat dengan jelas jumlah aktiva lancar yang dimiliki perusahaan pada kenyataannya lebih besar dari hutang lancar hal dapat kita lihat dari tahun ke tahun mengalami kenaikan dari 46,9\% tahun 1997 hingga 65,1\% tahun 1999 hanya saja sayangnya mengalami penurunan dari tahun sebelumnya, yaitu tahun 1997 dengan prosentase 46,9\% dari tahun 1996 yang hanya $47 \%$.

Dari tabel 5 ini juga kita melihat bahwa baik posisi aktiva lancar maupun hutang lancar mengalami penurunan prosentase pada tahun terakhir (1999) $16,1 \%$ untuk aktiva lancar dan $36,5 \%$ untuk hutang lancar. Namun jika kita melihat kembali ke tabel 3 tentang rasio keuangan maka situasi ini tidak akan terlalu banyak mengganggu likuiditas perusahaan karena justru pada tahun 1999 ini rasio likuiditas perusahaan karena justru berhasil melampui $100 \%$ baik untuk current ratio $286,4 \%$, cash ratio $111,2 \%$ dan quick ratio $189,9 \%$. Penurunan yang terjadi pada aktiva lancar tahun 1999 disebabkan oleh beberapa pos dan neraca per 31 Desember tahun 1996 - 1999 sebagai berikut :

\begin{tabular}{|c|c|c|c|c|}
\hline \multirow{2}{*}{ No } & \multirow{2}{*}{ Keterangan } & \multicolumn{2}{|c|}{ Jumlah } & \multirow{2}{*}{ Prosentase } \\
\hline & & 1999 & 1998 & \\
\hline 1 & Deposito Berjangka & 602.280 .300 & 1.012 .342 .100 & 40,5 \\
\hline 2 & Piutang Lain-lain & 259.187 .619 & 434.555 .335 & 40,4 \\
\hline 3 & Uang Muka & 16.460 .318 & 41.162 .462 & 60 \\
\hline 4 & Persediaan Suku Cadang & 51.928 .978 & 58.478 .109 & 11,2 \\
\hline 5 & Persediaan Lain-lain & 17.402 .816 & 20.342 .575 & 14,4 \\
\hline
\end{tabular}

Dari tabel 6 tersebut, kontribusi yang menyebabkan turunnya jumlah aktiva lancar disebabkan juga penurunan terhadap jumlah uang muka yang turun hingga mencapai $60 \%$ dan terdapat di perusahaan sehingga menimbulkan penurunan sampai mencapai $16,2 \%$ tehadap jumlah seluruh aktiva lancar.

Posisi uang kas perusahaan yang mengalami pertambahan maupun penurunan, sedangkan pada kenyataannya dari tahun ke tahun terus mengalami pertambahan Rp 339.995.300.000,(1996) hingga Rp 1.104.042.789.800,- (1998) berarti setiap tahunnya mengalami kenaikan masing-masing dari tahun 1996 - 1997,34,76\% dan yang terbesar mengalami kenaikan pada tahun 1997 - 1998 sebesar 140,96\% tetapi pada tahun terakhir 1999 bahkan mengalami penurunan sebesar $36,30 \%$ dari tahun sebelumnya.

\section{JURNAL}

MANAJEMEN

INDONESIA

Vol.17 No.3

Desember 2017

Tabel 5 Perbandingan

Posisi Pertambahan

dan Penurunan Aktiva

Lancar dan Hutang

Lancar Tahun 1996

1999

Sumber : Neraca per

31 Desember tahun

1996 - 1999 dan Hasil

Analisa

Tabel 6 Pos - Pos

dalam Neraca yang

Mengalami

Penurunan dari Tahun

$1996-1999$

Sumber : Neraca per

31 Desember Tahun

1996 - 1999 dan Hasil

Analisis

EVALUASI KINERJA KEUANGAN... 


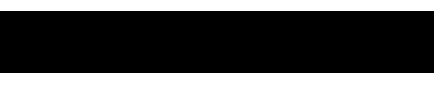

Untuk lebih jelasnya dapat kita lihat kenaikan maupun penurunan yang terjadi pada setiap komponen ataupun pos dari kas dan setara kas pada tabel berikut.

JURNAL

MANAJEMEN

INDONESIA

\section{Vol.17 No.3}

\section{Desember 2017}

Tabel 7 Pos - Pos

Kas \& Setara Kas

dalam Neraca yang

Mengalami

Pertambahan

ataupun Penurunan

Tahun 1996 - 1999

Sumber : Neraca

per 31 Desember

Tahun 1996 - 1999

dan Hasil Analisis

\begin{tabular}{|c|c|c|c|c|c|c|c|c|}
\hline \multirow{3}{*}{ Tahun } & \multicolumn{8}{|c|}{ Keterangan } \\
\hline & \multicolumn{2}{|c|}{ Kas \& Bank } & \multicolumn{2}{|c|}{ Deposito Berjangka } & \multicolumn{2}{|c|}{ Surat Berharga } & \multicolumn{2}{|c|}{ Letter of Credit } \\
\hline & Jumlah & $\%$ & Jumlah & $\%$ & Jumlah & $\%$ & Jumlah & $\%$ \\
\hline 1996 & $\begin{array}{r}34.669 .204 \\
\}\end{array}$ & $\uparrow 118$ & $\begin{array}{r}304.669 .204 \\
\}\end{array}$ & $\uparrow \quad 28,9$ & $\begin{array}{r}69.000 \\
\\
\}\end{array}$ & $0,00 \%$ & $\begin{array}{r}84.446 \\
\}\end{array}$ & $1,00 \%$ \\
\hline 1997 & $\begin{array}{r}65.184 .969 \\
\}\end{array}$ & $\uparrow 40,1$ & $\begin{array}{r}392.926 .250 \\
\}\end{array}$ & $\uparrow \quad 157,6$ & $\begin{array}{r}69.000 \\
\\
\}\end{array}$ & $362,30 \%$ & - & $0,00 \%$ \\
\hline 1998 & $\begin{array}{r}91.381 .689 \\
\}\end{array}$ & $\uparrow 10,1$ & $\begin{array}{r}1.012 .342 .100 \\
\}\end{array}$ & $\uparrow \quad 40,5$ & $\begin{array}{r}319.000 \\
\}\end{array}$ & $0,00 \%$ & - & \\
\hline 1999 & 100.641 .113 & & 602.280 .300 & & 319.000 & & - & \\
\hline
\end{tabular}

Berdasarkan tabel 7, maka pos-pos yang mengalami kenaikan pada Kas \& Setara Kas adalah kas dan bank berikut Deposito Berjangka, untuk surat berharga dan Letter of Credit hanya mendapat kenaikan untuk surat berharga mencapai 362,3\% dari tahun 1997 yang berjumlah Rp 69.000.000,- menjadi Rp 319.000.000,- di tahun 1998 sedangkan untuk tahun sebelumnya 1997 dan sesudahnya tahun 1998 tidak terdapat kenaikan. Sedangkan untuk letter of credit hanya terdapat pada tahun 1996 hanya sebesar Rp 684.446.000,- sedangkan untuk tahun-tahun setelah itu tidak terdapat lagi.

Pada kas dan bank dari tahun 1996 - 1999 memang senantiasa mengalami kenaikan di mana tahun 1996 - 1997 naik hingga 88\% tahun 1997 -1998 naik sebesar 40,1\% dan 1998 1999 naik sebesar 10,1\%. Namun jika dilihat dari besarnya prosentase kenaikan, maka dapat diketahui bahwa besar kenaikan menurun sehingga untuk tahun 1999 saja besarnya hanya 10,1\% dari tahun sebelumnya yang besarnya 40,1\% untuk tahun 1998

Sedangkan apabila kita kembali lagi memperhatikan neraca terutama pada pos kewajiban maka dapat dikatakan bahwa kewajiban jangka pendek mengalami kenaikan dan penurunan dari Rp 532.212.965.000,- (1996) - Rp 996.352.580.000,- (1998). Jadi untuk tiap tahunnya mengalami kenaikan masing-maing 37,56\% (1996 - 1997) dan 35,36\% (1997 - 1998) sedangkan penurunan terjadi pada tahun (1998 - 1999) sebesar 36,52\%.

Untuk lebih jelasnya kita dapat melihat komponen-komponen yang termasuk kewajiban jangka pendek pada tabel 8 berikut ini : 


\begin{tabular}{|c|c|c|c|c|c|c|c|c|c|c|c|c|c|c|}
\hline \multirow{3}{*}{ Tahun } & \multicolumn{14}{|c|}{ Keterangan } \\
\hline & \multicolumn{2}{|c|}{ Pinjaman } & \multicolumn{2}{|c|}{ Hutang Usaha } & \multicolumn{2}{|c|}{ Hutang Pajak } & \multicolumn{2}{|c|}{$\begin{array}{l}\text { Hutang jk pjg yg jtuh } \\
\text { tempo }\end{array}$} & \multicolumn{2}{|c|}{ Hutang lain } & \multicolumn{2}{|c|}{ Biaya yg masih hrs dibayar } & \multicolumn{2}{|c|}{$\begin{array}{c}\text { Pendapatan ditrima di } \\
\text { muka }\end{array}$} \\
\hline & Jumlah & $\%$ & Jumlah & $\%$ & Jumlah & $\%$ & Jumlah & $\%$ & Jumlah & $\%$ & Jumlah & $\%$ & Jumlah & $\%$ \\
\hline \multirow[t]{2}{*}{1996} & 100.127 .373 & & 198.952 .635 & & 57.734 .524 & & 60.260 .461 & & 30.377 .354 & & 83.419 .252 & & 1.352 .366 & \\
\hline & \} & $\uparrow 439,9$ & \} & $\uparrow \quad 34,4$ & \} & $\uparrow \quad 11,6$ & \} & $\downarrow 13$ & \} & $33,10 \%$ & \} & $8,30 \%$ & \} & $24,50 \%$ \\
\hline \multirow[t]{2}{*}{1997} & 240.230 .784 & & 267.344 .494 & & 64.421 .333 & & 52.425 .538 & & 20.307 .794 & & 90.334 .640 & & 1.020 .979 & \\
\hline & \} & $\downarrow \quad 39,7$ & \} & $\uparrow 84,1$ & \} & $\uparrow \quad 28,8$ & \} & $\uparrow \quad 54,6$ & \} & $716,10 \%$ & \} & $28,30 \%$ & \} & $32,50 \%$ \\
\hline \multirow[t]{2}{*}{1998} & 108.802 .294 & & 492.329 .271 & & 82.991 .788 & & 81.054 .502 & & 165.727 .580 & & 64.757 .752 & & 689.393 & \\
\hline & \} & $\downarrow \quad 64,5$ & \} & $\downarrow 45,7$ & \} & & \} & $\downarrow \quad 65,4$ & \} & $2,20 \%$ & \} & $32,20 \%$ & \} & $24,21 \%$ \\
\hline 1999 & 38.596 .650 & & 267.312 .552 & & 82.991 .788 & & 28.015 .937 & & 169.300 .572 & & 443.927 .386 & & 2.258 .191 & \\
\hline
\end{tabular}

Intinya walaupun jumlah kas dan setara kas yang dimiliki perusahaan tidak sebesar jumlah kewajiban lancar maupun secara keseluruhan, salah satu komponen dari aktiva lancar ini bersama komponen-komponen lainnya dapat menutupi jumlah kewajiban lancarnya. Hanya sayangnya walau sebenarnya jumlah kas dan setara kas nelum sebanding dengan kewajiban lancar tetapi jumlah ini sudah termasuk besar dilihat baik dari neraca maupun rasio keuangan. Indikasi yang ditimbulkan adalah inefisiensi perusahaan apabila uang kas tersebut tidak dimanfaatkan secara maksimal karena terjadi "pengangguran kas" dalam produktivitas.

Dari tabel 7 dan 8 maka terlihatlah bahwa jumlah antara "kas dan setara kas" terhadap hutang lancar tidak cukup seimbang karena beberapa pos "kas dan setara kas" lebih kecil dari hutang lancar, walaupun begitu juga melihat jumlah keseluruhan dari aktiva lancar bahkan melebihi jumlahnya dari hutang lancar.

Pada umumnya perhitungan quick ratio tidak harus dilakukan, namun bagi perusahaan ini diperlukan untuk melihat posisi perediaan ini, mengapa? Karena persediaan yang tidak mencukupi dapat mengganggu produktivitas perusahaan sedangkan persediaan yang berlebihan dapat menimbulkan inefisiensi bagi perusahaan.

Tabel 3 pada Daftar Rasio Keuangan tahun 1996-1999 menunjukkan peningkatan dan penurunan untuk tiap tahunnya; seperti dari 1996-1999, mengalami penurunan 0,85\%, sementara dari tahun 1996-1999 mengalami kenaikan sebesar masing-masing 39,32\% dan $16,56 \%$ dari tahun sebelumnya.

Sedangkan apabila kita percaya neraca pun, akan terlihat juga baik kenaikan ataupun penurunan persediaan seperti tahun 1996-1999 dimana persediaan sejumlah Rp 369.095.067.000,- mengalami kenaikan 36\% sedangkan tahun 1996-1999 mengalami penurunan sebesar 6,7\% dari Rp 505.563.067.000,- (1997) menjadi Rp 471.371.417,(1998) dan dari tahun ini ke tahun 1999 sebesar Rp 523.544/380.000,- atau 11,1\%.

Walaupun pada dasarnya jumlah persediaan mengalami kenaikan dan penurunan, namun secara keseluruhan persediaan yang dimiliki cukup banyak dan ini harus dimanfaatkan sebaikbaiknya untuk kegiatan produksi, apabila tidak, persediaan yang jumlahnya cukup besar ini dapat menimbulkan in efisiensi bagi perusahaan karena terjadi penumpakan di gudang.

\section{Kesimpulan dan Saran}

\subsection{Kesimpulan}

Berdasarkan pembahasan sebelumnya dapat disimpulkan bahwa Evaluasi Kinerja Keuangan PT Pupuk Sriwijaya untuk tahun 1996 - 1999 dikategorikan sangat likuid, karena ketiga unsur rasio yang terdapat di dalamnya mengalami kenaikan hanya saja pengaruh yang ditimbulkannya menyebabkan perusahaan cenderung mengalami inefisiensi dalam pemanfaatan
Tabel 8 Prosentase

Peningkatan dan

Penurunan pada Pos -

Pos Hutang Lancar

dalam Neraca

Sumber: Hasil Analisis

EVALUASI KINERJA KEUANGAN... 
kas dan persediaan. Hal ini dapat dimaklumi karena perusahaan terutama PT Pupuk Sriwijaya merupakan perusahaan pemerintah dibawah naungan BUMN sehingga perusahaan ini mendapat subsidi dari pemerintah.

\section{JURNAL}

MANAJEMEN

INDONESIA

\section{Vol.17 No.3}

Desember 2017

\subsection{Saran}

Perusahaan harus senantiasa mengantisipasi segala kemungkinan yang bisa saja terjadi baik di luar maupun di dalam perusahaan. Pelaksanaan pengawasan terhadap pelaksanaan semua tugas di setiap lini dalam perusahaan sehingga dapat bekerja dengan sebaik mungkin sehingga tercapai tujuan yang telah ditetapkan sebelumnya

\section{Daftar Pustaka}

Alwi, S. (2001). Manajemen Sumber Daya Manusia Strategi Keunggulan Kompetitif. Yogyakarta: BPFE.

Brigham, E. F., Gapenski, L. C., \& Ehrhardt, M. C. (1998). Financial Management; Theory and Practice (Book and diskette package). Harcourt College Publishers.

Brigham, E. F., \& Houston, J. F. (2001). Manajemen Keuangan. Buku 1 edisi 8. Jakarta: Erlangga.

Munawir, S. (1981). Analisa laporan keuangan. Liberty.

Purwanto, M. N. (2000). Prinsip-prinsip dan teknik evaluasi pengajaran. Remaja Rosdakarya.

Reksoprayitno, S. (2000). Pengantar ekonomi makro. BPFE, Yogyakarta.

Riyanto, B., \& Perusahaan, D. D. P. (1998). Edisi 4. Dasar-dasar Pembelanjaan Perusahaan, BPFE, Yogyakarta.

Syamsuddin, L. (2007). Manajemen Keuangan Perusahaan: Konsep Aplikasi dalam Perencanaan, Pengawasan, dan Pengambilan Keputusan. Jakarta: PT. Raja Grafindo Persada. 